\title{
Rotujen välisten erojen arviointi ei riitä rotujen suojelullisen arvon määrittämiseen
}

Miika Tapio ${ }^{1)}$, Ilma Grigaliunaite ${ }^{1)}$, Lars-Erik Holm ${ }^{2)}$, Sven Jeppsson ${ }^{3)}$, Juha Kantanen ${ }^{1)}$, Ilona Miceikiene ${ }^{4)}$, Ingrid Olsaker ${ }^{5}$, Haldja Viinalass ${ }^{6}$ ja Emma Eythorsdottir ${ }^{7}$

${ }^{1)}$ MTT Agrifood Research Finland, 31600 Jokioinen, Finland, etunimi.sukunimi@mtt.fi

${ }^{2)}$ Danish Institute of Agricultural Science, 8830 Tjele, Denmark

${ }^{3}$ Swedish Board of Agriculture, 55182 Jönköping, Sweden

${ }^{4)}$ Lithuanian Veterinary Academy, Tilzes 18, 3022 Kaunas, Lithuania

${ }^{5)}$ The Norwegian School of Veterinary Science, 0033 Oslo, Norway

${ }^{6)}$ Institute of Animal Science of Estonian Agricultural University, 51014 Tartu, Estonia

${ }^{7)}$ Agricultural Research Institute, Keldnaholti, 112 Reykjavik, Iceland

\section{Johdanto}

Yksi YK:n elintarvike- ja maatalousjärjestön (FAO) tärkeänä pitämistä tehtävistä on kotieläinrotujen välisten geneettisten etäisyyksien määrittäminen DNA:n lyhyiden peräkkäisten toistojen alueiden pituusvaihtelua eli ns. mikrosatelliitti vaihtelua tutkimalla. Mikäli rodun geneettiset etäisyydet muihin rotuihin ovat suuret on kyseessä ainutlaatuinen rotu. Kun rotujen ainutlaatuisuudet on määritetty, voidaan "tavallisempien" rotujen suojeluun käytettyjä resursseja siirtää ainutlaatuisempien rotujen suojeluun. Yleisemmin rodun suojeluarvo voidaan määritellä muutoksena, jonka rodun sukupuutto aiheuttaa lajin monimuotoisuuteen. Kotieläinrotujen suojeluarvo on useimmiten (esim. Thaon d'Arnoldi ym. 1998, Barker 2001, Canon ym. 2001) määritetty Weitzmanin (1992) menetelmällä, joka hyödyntää nimenomaan FAO:n peräänkuuluttamia geneettisiä etäisyyksiä. Petit ym. (1998) esittivät vaihtoehtoisen tavan mitata rodun suojeluarvoa, mikä perustuu rotujen yhteisen geenidiversiteetin tai toisena vaihtoehtona alleelirikkauden muutokseen lisättäessä kyseinen populaatio muiden populaatioiden joukkoon. Geenidiversiteetti on yleisin käytetty geneettisen muuntelun mitta ja se on yhtä kuin todennäköisyys, että kahdella satunnaisella kromosomilla on geenistä eroavat muodot eli erilaiset alleelit. Alleelirikkaus puolestaan on odotettu erilaisten alleelien lukumäärä tietyssä näytekoossa. Sekä rodun ainutlaatuisuus että rodun sisäinen muuntelu vaikuttaa siihen, miten rodun lisääminen muiden rotujen joukkoon vaikuttaa rotujen yhteisen perinnöllisen monimuotoisuuden määrään.

Tutkimuksessa selvitettiin riittääkö tieto populaatioiden erilaistumisesta rotujen suojeluarvon määrittämiseen. Tässä tarkoituksessa verrattiin Weitzman (1992) menetelmän osoittamaa suojeluarvoa ja Petit ym. (1998) mukaista rodun vaikutusta kokonaismuunteluun mitattuna sekä geenidiversiteettinä että alleelirikkautena. Tutkittavana vertailussa oli pohjoiseurooppalaisten lammasrotujen mikrosatelliittiaineisto.

\section{Materiaali ja menetelmät \\ Lammasrodut ja tutkitut merkkigeenit}

Tutkimuksessa tarkasteltiin 32 Euroopan pohjoisosien lammasrotua. Rodusta tyypitettiin 13-55 yksilöä. Rodut ja tutkittujen yksilöiden määrät olivat: suomenlammas (30 lammasta), Kainuun harmas-lammas (30), ahvenanmaanlammas (25), Vienan lammas (31), romanov (31), Ruotsin hienovilla (32), Ruotsin rya (31), Gotlannin turkislammas (30), Ruotsin dala turkislammas (29), Gotlannin gute (20), Ruotsin metsälammas (38), ruotsalainen roslaginlammas (30), Tanskan maatiaislammas (21), Tanskan valkeapäinen nummilammas (28), texel (24), Grönlannin lammas (17), färsaartenlammas (21), Norjan steigar (29), Norjan dala-lammas (55), Norjan rygja (28), cheviot (28), Norjan lyhythäntäinen lammas (30), Norjan vanha lyhythäntäinen lammas (29), Norjan villilammas (37), Norjan troender (25), fuglestad (13), islanninlammas (30), islanninlampaan johtajalammaskanta (35), Liettuan karkeavillainen lammas (30), Liettuan mustakasvoinen lammas (30), Latvian mustapäinen lammas (32) ja Viron Ruhnu-saaren lammas (24). Yhteensä 923 lampaasta määritettiin 22 eri mikrosatelliittitoistojakson pituusvaihtelu. Tutkitut mikrosatelliitit olivat OarFCB128, OarFCB304, OarFCB48, OarHH47, McM527, MAF65, MAF48, MAF36, MAF214, INRA023, BM8125, BM0757, BM1818, BM6526, BM1314, BM4621, BM6506, OarCP38, OarCP20, OarCP34, CSSM31 ja OarVH72. 


\section{Tilastolliset analyysit}

Weitzmanin menetelmän mukainen yksittäisen rodun sukupuutosta johtuva geneettisen monimuotoisuuden häviämä, joka perustuu geneettisiin etäisyyksiin ja niiden perusteella rakennettuun suurimman uskottavuuden puudiagrammiin, laskettiin Canonin ym. (2001) ohjelmalla. Analyysissä käytettiin $\mathrm{D}_{\mathrm{A}}$ geneettistä etäisyyttä (Nei ym. 1983). Populaation vaikutus populaatioiden yhteiseen geenidiversiteettiin ja alleelirikkauteen laskettiin kuten Petit ym. (1998) heidän CONTRIB ohjelmallaan (saatavissa http://www.pierroton.inra.fr/genetics/labo/Software/) ja yksittäisten geenien tulosten perusteella laskettiin yhteisarviot ohjelman ohjeiden mukaisesti. Samalla ohjelmalla määritettiin myös populaatioiden sisäisen muuntelun ja populaatioiden ainutlaatuisuuden merkitykset populaation vaikutuksessa kokonaismonimuotoisuuteen.

\section{Tulokset ja tulosten tarkastelu}

Perinnöllisen monimuotoisuuden häviämä rodun sukupuuton vuoksi Weitzmanin (1992) monimuotoisuusmääritelmän mukaisesti ja Petitin ym. (1998) rodun osuus kokonaisvaihtelussa korreloivat positiivisesti, mutta erittäin heikosti eikä korrelaatio ollut tilastollisesti merkitsevä (Kuva 1a ja 1b). Tarkasteltaessa erikseen rodun sisäisen muuntelun ja populaation ainutlaatuisuuden komponentteja vaikutuksessa populaatioiden kokonaismonimuotoisuuteen ja Weitzmanin menetelmän osoittamaa rodun suojeluarvoa havaittiin rodun ainutlaatuisuuskomponentin korreloivan voimakkaan positiivisesti Weitzman arvon kanssa (Kuva 1c ja 1d), kun taas rodun sisäisen muuntelun komponentti korreloi voimakkaan negatiivisesti tämän arvon kanssa (Kuva 1e ja 1f). Weitzman menetelmän mukainen suojeluarvo ja Petitin ym. mukainen suojeluarvo korreloi heikosti, koska populaation ainutlaatuisuus komponentti korreloi voimakkaan negatiivisesti populaation sisäisen vaihtelun komponentin kanssa $(-0.96<\mathrm{r}<-0.90)$. Esimerkiksi Weitzman menetelmä antaa suurimman suojeluarvon (0.076) populaatiolle, joka on populaatioista kaikista ainutlaatuisin (ainutlaatuisuus komponentti geenidiversiteetille $=0.013$ ja alleelirikkaudelle $=0.013$ ). Tämän rodun sisäinen muuntelu on kuitenkin keskimääräistä alhaisempi, mistä johtuu negatiivinen populaation sisäisen vaihtelun komponentti (geenidiversiteetille $=-0.011 \mathrm{ja}$ alleelirikkaudelle $=-0.012$ ). Weitzman suojeluarvo on alhaisin (0.011) rodulle, joka ei ole voimakkaasti erilaistunut muista (geenidiversiteetille ainutlaatuisuuskomponentti $=-0.003$ ja vastaava alleelirikkaudelle $=-0.006$ ), mutta jonka sisäisen vaihtelun komponentit ovat suurimpien joukossa (geenidiversiteetille $=0.002$ ja alleelirikkaudelle $=0.005$ ). Rodun ainutlaatuisuuskomponentti ja Weitzmanin monimuotoisuusmääritelmä perustuvat vain geneettiseen erilaistumiseen ja siten näiden perusteella päädyttäisiin suojelemaan voimakkaan sisäsiittoisia rotuja teholliselta populaatiokooltaan suurempien populaatioiden kustannuksella. Weitzmanin menetelmän kehitelmissä on olemassa menetelmiä tämän vinoutuman korjaamiseen esimerkiksi asettamalla rodun sukupuuttotodennäköisyys sisäisen muuntelun perusteella, jolloin vähän muuntelevan rodun "geneettinen sukupuutto" (sisäisen muuntelun häviäminen) on todennäköisempi kuin runsaasti muuntelevan (García ym. 2002) ja tämän korkeamman sukupuuttotodennäköisyyden vuoksi rodun merkitystä pienennetään. Garcían ym. määrittelemä "geneettinen sukupuutto" ei kuitenkaan välttämättä tarkoita todellista sukupuuttoa ja toisaalta todellisiin sukupuuttotodennäköisyyksiin vaikuttaa hyvin moni muukin tekijä. Tämän vuoksi on selkeämpää ottaa sisäinen muuntelu huomioon suoraan suojeluarvoa määritettäessä.

Petitin ym. (1998) mukaisessa arvioinnissa populaatioiden perinnöllistä monimuotoisuutta mitattiin geenidiversiteettinä ja alleelirikkautena. Näiden kahden tavan välillä tehtävä päätös riippuu pidetäänkö tärkeimpänä lähitulevaisuutta (korkeintaan muutamaa kymmentä eläinsukupolvea) vai kaukaisempaa tulevaisuutta. Geenidiversiteetti on verrannollinen lyhyen aikajakson valintavasteeseen, mutta alleelirikkaus on verrannollinen rajaan, johon asti valinnalla voidaan vaikuttaa rodun ominaisuuksiin (esim. James 1971). Tässä tutkimuksessa tehdyn populaation vaikutuksen ja Weitzmanin menetelmän vertaamisen kannalta kahdella tavalla mitata monimuotoisuutta ei ollut eroa.

\section{Johtopäätökset}

Rodun suojeluarvon määrittäminen yksin rodun erilaistumiseen perustuen on kyseenalaista, koska rodun suojelullinen arvo erilaistumisen vuoksi korreloi voimakkaan negatiivisesti rodun sisäisen vaihtelun kanssa. Rotujen asettamisessa tärkeysjärjestykseen on pyrittävä käyttämään menetelmiä, jotka ottavat sekä erilaistumisen että rodun sisäisen muuntelun samanaikaisesti huomioon. 

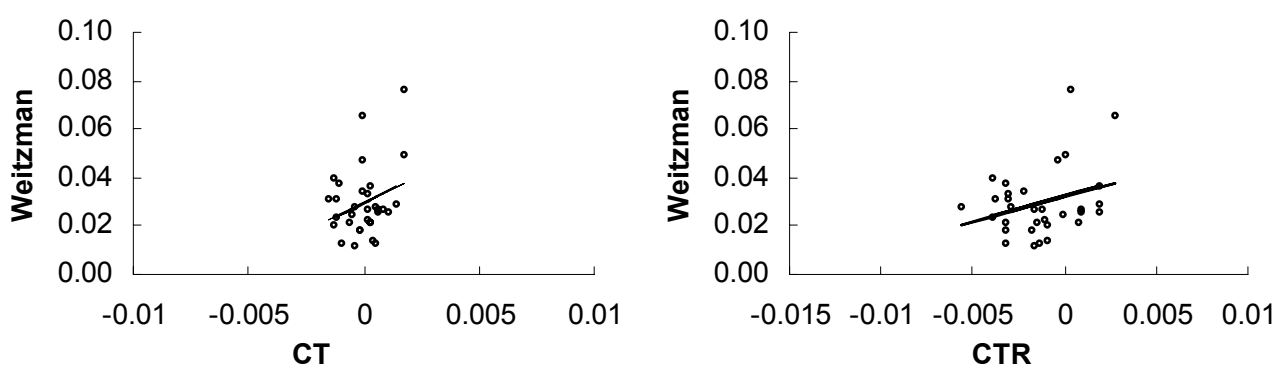

a) $r=0.286 ; p=0.11$

b) $r=0.306 ; p=0.09$
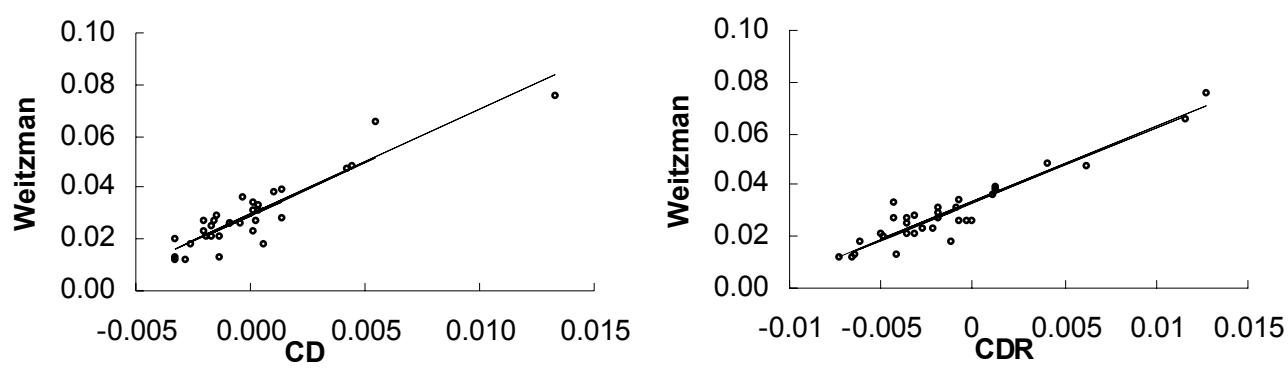

c) $r=0.918 ; p<0.01$

d) $r=0.942 ; p<0.01$
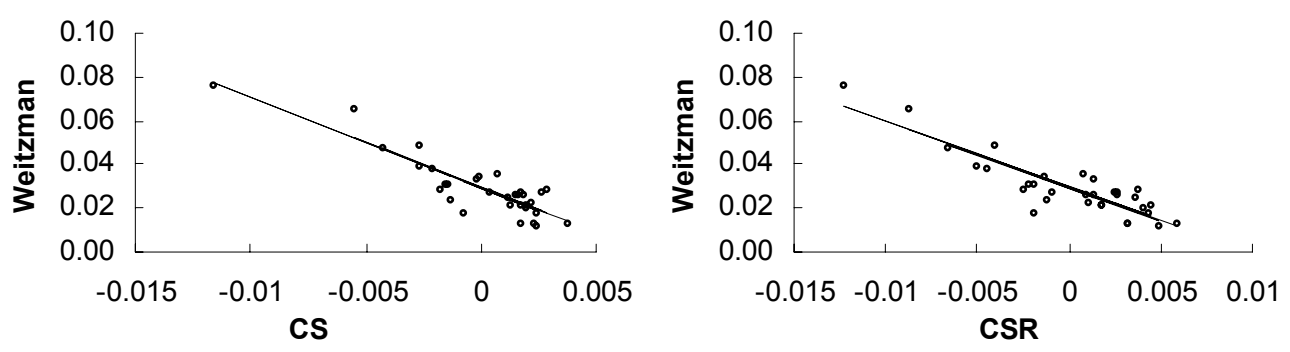

e) $r=-0.889 ; p<0.01$

f) $r=-0.883 ; p<0.01$

Kuva 1. Weitzmanin (1992) menetelmän mukaisen rodun sukupuuton aiheuttaman monimuotoisuuden häviämä verrattuna Petit ym. (1998) mukaiseen populaation vaikutukseen kokonaisvaihteluun (a geenidiversiteetti, b alleelirikkaus). Lisäksi Weitzmanin monimuotoisuuden häviämää on verrattu rodun ainutlaatuisuuden vaikutukseen (c geenidiversiteetti ja d alleelirikkaus) ja rodun sisäisen vaihtelun vaikutukseen (e geenidiversiteetti ja f alleelirikkaus).

\section{Kirjallisuus}

Barker, J.S.F., Tan, S.G., Moore, S.S., Mukherjee, T.K., Matheson, J.-L. \& Selvaraj, O.S. 2001. Genetic variation within and relationships among populations of Asian goats (Capra hircus). J. Anim. Breed. Genet. 118: 213-233.

Cañón, J., Alexandrino, P., Bessa, I., Carleos, C., Carretero, Y., Dunner, S., Ferran, N., Garcia, D., Jordana, J., Laloë, D., Pereira, A., Sanchez, A. \& Moazami-Goudarzi, K. 2001. Genetic diversity measures of local European beef cattle breeds for conservation purposes. Genet. Sel. Evol. 33: 311-332.

García, D., Corral, N. \& Cañón, J. 2002. Further developments on Weitzman's approach to assess conservation of genetic diversity. $7^{\text {th }}$ WCGALP. Montpellier. $\mathrm{N}^{\mathrm{o}} 26-23$.

James, J.W. 1971. The founder effect and response to articial selection. Genet. Res. 16: 241-250.

Nei, M., Tajima, F. \& Tateno, Y. 1983. Accuracy of genetic distances and phylogenetic trees from molecular data. J. Mol. Evol. 19: 153-170.

Petit, R.J., El Mousadik, A. \& Pons, O. 1998. Identifying populations for conservation on the basis of genetic markers. Conserv. Biol. 12: 844-855.

Thaon d' Arnoldi, C., Foulley, J-L. \& Ollivier, L. 1998. An overview of the Weitzman approach to diversity. Genet. Sel. Evol. 30: 149-161.

Weitzman, M.L. 1992. On diversity. Q. J. Econ. 107: 363-405. 